\title{
Economic Impact of Harvesting Corn Stover under Time Constraint: The Case of North Dakota
}

\author{
Thein A. Maung and Cole R. Gustafson \\ Department of Agribusiness and Applied Economics, North Dakota State University, Fargo, ND 58108, USA
}

Correspondence should be addressed to Thein A. Maung; thein.maung@ndsu.edu

Received 3 February 2013; Accepted 7 April 2013

Academic Editor: Tun-Hsiang Edward Yu

Copyright (C) 2013 T. A. Maung and C. R. Gustafson. This is an open access article distributed under the Creative Commons Attribution License, which permits unrestricted use, distribution, and reproduction in any medium, provided the original work is properly cited.

\begin{abstract}
This study examines the impact of stochastic harvest field time on profit maximizing potential of corn cob/stover collection in North Dakota. Three harvest options are analyzed using mathematical programming models. Our findings show that under the first corn grain only harvest option, farmers are able to complete harvesting corn grain and achieve maximum net income in a fairly short amount of time with existing combine technology. However, under the second simultaneous corn grain and cob (one-pass) harvest option, farmers generate lower net income compared to the net income of the first option. This is due to the slowdown in combine harvest capacity as a consequence of harvesting corn cobs. Under the third option of separate corn grain and stover (two-pass) harvest option, time allocation is the main challenge and our evidence shows that with limited harvest field time available, farmers find it optimal to allocate most of their time harvesting grain and then proceed to harvest and bale stover if time permits at the end of harvest season. The overall findings suggest is that it would be more economically efficient to allow a firm that is specialized in collecting biomass feedstock to participate in cob/stover harvest business.
\end{abstract}

\section{Introduction}

The US ethanol demand has steadily increased following passage of Renewable Fuel Standard (RFS) and the Energy Independence and Security Act of 2007 (EISA). Most domestic ethanol production utilizes corn grain as feedstock. Rising corn prices are encouraging current and potential ethanol producers to seek alternative feedstocks, especially cellulosic sources. EISA defines three classes of biofuels, conventional, advanced, and cellulosic. These classes are differentiated based on potential reduction of greenhouse gas (GHG) emissions of $20 \%, 50 \%$, and $60 \%$, respectively. Cellulosic biofuels are shown to have higher GHG offset rates than grain-based biofuels [1]. Comparatively more GHG can be reduced through the use of cellulosic feedstock such as corn stover comprised of stalk, leaves, husks, and cobs than corn grain to produce biofuels. Because of its potential in reducing GHG emissions, corn-stover-based ethanol can be qualified as cellulosic biofuel per the federally mandated RFS. By 2022, cellulosic ethanol consumption of 16 billion gallons per year will be required, creating a niche market opportunity.
Existing biofuel producers are striving to develop cellulosic biofuels that qualify under EISA.

Greater reliance on corn stover as a bioenergy feedstock poses a logistical challenge for farmers who face limited harvest field time. Harvest in fall is especially difficult in North Dakota because cool temperatures and wet conditions coupled with limited harvest field time can result in a sizeable acreage being left unharvested. According to O'Brien [2], about 68.7 million bushels of corn in North Dakota were reported to be left unharvested in 2009. Collecting corn $\mathrm{cob} /$ stover can be a challenge while trying to get the grain harvest done on time. In addition, corn producers do not have sufficient information to evaluate the economic investment returns from producing corn cob/stover.

Many studies [3-8] have examined the economics of corn stover supply for biofuel production. While these studies have focused on estimating costs of harvesting corn stover as a whole, only few studies have particularly given emphasis on examining the economics of supplying corn cobs as a potential feedstock using up-to-date harvesting technologies. Chippewa Valley Ethanol Company (CVEC) 
[9] has published a feasibility report on the use of corn cobs as a sustainable source of biomass for providing thermal energy for its corn grain ethanol process. The company utilized two different cob harvest systems to demonstrate cob harvesting on 3,200 acres of land. Zych [10] estimated potential US corn cob production and reviewed logistical issues associated with collection and storage of corn cobs. The aforementioned studies did not take into account the viability and profitability of farmer investment in cob and stover harvest business. Using a stochastic linear programming model, Bouzaher and Offutt [11] investigated the feasibility and profitability of farm residue collection. In their model, they considered the sensitivity of grain and residue collection to the availability of days suitable for field work at harvest time. Apland et al. [12] employed the discrete stochastic programming model to examine the impact of production process, sequential decision making, and fall field time availability on crop residue supply in midwestern US grain farms. Recently, Erickson and Tyner [13] examined the economics of harvesting corn cobs for energy generation using their farm plan model. However, the authors did not consider harvest field time constraint in their model.

Using North Dakota as a case study, the goal of this paper is to investigate the economics of producing corn cob and stover under limited harvest field time. Specifically, our purpose is to assess the viability of farmers' investment in corn cob and stover harvest business under three different harvest options, and to analyze economic tradeoffs between corn grain and cob/stover harvest activities given limited availability of harvest field time. In addition, the impact of changes in farm size and tillage practice on net farm revenue will be examined. The three harvest options which we subsequently address include: (i) corn grain only harvest option, (ii) simultaneous corn grain and cob (one-pass) harvest option, and (iii) separate corn grain and stover (twopass) harvest option. Results from this study will contribute to the growing literature on the economics of producing alternative feedstock in the United States.

\section{Methodology, Data Description, and Assumptions}

This section starts with the descriptions of three harvest models followed by yield and cost estimation for corn grain, cob, and stover and the descriptions of data and assumptions used in the models.

2.1. Corn Grain Harvesting. The following linear programming model which maximizes net income is used to examine the production of corn grain:

$$
\begin{array}{r}
\operatorname{Max} \quad \pi=P_{c} \cdot Q_{c}-\sum_{j=1}^{4} C_{j} X_{j}, \\
\text { s.t. } \quad-\sum_{j=1}^{4} \operatorname{Yld}_{c, j} X_{j}+Q_{c} \leq 0,
\end{array}
$$

$$
\begin{aligned}
& a_{j} X_{j} \leq \widetilde{\mathrm{CFT}}_{j}, \\
& b_{j} X_{j} \leq \widetilde{\mathrm{LFT}}_{j}, \\
& \sum_{j=1}^{4} X_{j} \leq L, \\
& Q_{c} \geq 0 ; \quad X_{j} \geq 0, \quad j=1, \ldots, 4 .
\end{aligned}
$$

Based on Apland [14] and Bouzaher and Offutt [11], we assume that $j=1, \ldots, 4$ represent four two-week harvest periods which run from the end of September till the end of November. $P_{c}$ is the price of corn grain in dollar per short ton. $Q_{c}$ is denoted as the quantity of corn grain sold in tons. $C_{j}$ is defined as corn grain harvest and production costs in dollar per acre. $X_{j}$ is denoted as acres of corn grain harvested. Yld $_{c, j}$ represents per acre corn grain yield in each harvest period $j$. $a_{j}$ and $b_{j}$ are, respectively, denoted as labor and combine time required per acre to harvest corn grain in each harvest period. Both combine and labor times are, respectively, constrained by $\widetilde{\mathrm{CFT}}_{j}$ and $\widetilde{\mathrm{LFT}}_{j}$ which represent stochastic combine and labor harvest field times expressed in hours. $L$ is defined as total farm land acres that are available for corn grain harvest.

The objective function (see (1)) of the optimization problem is to quantify the net return of corn grain harvesting at the farm level. Equation (2) balances corn grain sales with production. Equations (3) and (4) constrain the total amount of combine and labor times available for harvesting corn grain. Equation (5) limits the amount of land available for grain farming.

2.2. Simultaneous Corn Grain and Cob (One-Pass) Harvesting . The following linear programming model is used to examine the viability of producing corn grain and cob simultaneously:

$$
\begin{array}{ll}
\operatorname{Max} & \pi=P_{c} \cdot Q_{c}+P_{\mathrm{cb}} \cdot Q_{\mathrm{cb}}-\sum_{j=1}^{4} C_{j} X_{j}-\sum_{j=1}^{4} D_{j} X_{j}, \\
\text { s.t. } & -\sum_{j=1}^{4} \mathrm{Yld}_{c, j} X_{j}+Q_{c} \leq 0, \\
& -\sum_{j=1}^{4} \mathrm{Yld}_{\mathrm{cb}, j} X_{j}+Q_{\mathrm{cb}} \leq 0 \\
& e_{j} X_{j} \leq \widetilde{\mathrm{CFT}}_{j}, \\
& f_{j} X_{j} \leq \widetilde{\mathrm{LFT}_{j}}, \\
& \sum_{j=1}^{4} X_{j} \leq L, \\
& Q_{c} \geq 0 ; \quad Q_{\mathrm{cb}} \geq 0 ; \quad X_{j} \geq 0, \quad j=1, \ldots, 4 .
\end{array}
$$

$P_{\mathrm{cb}}$ is the price of corn cob in dollar per short ton. $Q_{\mathrm{cb}}$ is denoted as the quantity of corn cob sold in ton. $D_{j}$ is defined 
as corn cob harvest cost in dollar per acre. $X_{j}$ is denoted as acres of corn grain or cob harvested. $\mathrm{Yld}_{\mathrm{cb}, j}$ represents per acre corn cob yield in each harvest period $j . e_{j}$ is denoted as corn combine and cob harvester (attached to the back of combine) times required per acre to harvest corn grain and cob in each harvest period and is constrained by available combine harvest field time. Similarly, $f_{j}$ is denoted as labor time required per acre to harvest corn grain and cob and is restricted by the available labor harvest field time. $L$ is defined as total farm land acres available for corn grain and cob harvest. The one-pass cob harvest method is employed in this study because of its simplicity, efficiency, and commercial availability. Detailed explanations and specifications of the cob harvester are described in the subsequent Section 2.6.

The objective function (see (7)) of the optimization problem is to quantify the net return potential associated with the adoption of corn cob harvesting technology. Equation (9) balances corn cob sales with production. Equations (10) and (11) constrain the total amount of machine and labor time available for harvesting corn grain and cob simultaneously. Equation (12) limits the amount of land available for corn grain and cob farming.

2.3. Separate Corn Grain and Stover (Two-Pass) Harvesting. The linear programming model based on Bouzaher and Offutt's model [11] which maximizes net return is used to investigate the profitability of harvesting corn grain and stover separately. The model is written as follows:

$$
\begin{aligned}
\operatorname{Max} & \pi=P_{c} \cdot Q_{c}+P_{c s} \cdot Q_{c s}-\sum_{j=1}^{4} C_{j} X_{j}-\sum_{i=2}^{4} \sum_{j=1}^{3} G_{i, j} Y_{i, j}, \\
\text { s.t. } & -\sum_{j=1}^{4} \mathrm{Yld}_{c, j} X_{j}+Q_{c} \leq 0 \\
& -\sum_{i=2}^{4} \sum_{j=1}^{3} Y_{i, j}+Q_{c s} \leq 0, \\
& a_{j} X_{j} \leq \widetilde{\mathrm{CFT}}_{j} \quad j=1, \ldots, 3, \\
& b_{1} X_{1} \leq \widetilde{\mathrm{LFT}}_{1}, \\
& b_{i} X_{i}+\sum_{j=1}^{i-1} h_{i, j} Y_{i, j} \leq \widetilde{\mathrm{LFT}}_{i} i=2,3, \\
& \sum_{j=1}^{3} h_{4, j} Y_{4, j} \leq \widetilde{\mathrm{LFT}}_{4}, \\
& \sum_{j=1}^{i-1} k_{i, j} Y_{i, j} \leq \widetilde{\mathrm{BFT}}_{i} \quad i=2, \ldots, 4 \\
& \sum_{j=1}^{3} X_{j} \leq L,
\end{aligned}
$$

$$
\begin{aligned}
& \sum_{i=j+1}^{4} Y_{i, j}-m_{j} X_{j} \leq 0 \quad j=1, \ldots, 3 \\
& Q_{c} \geq 0 ; \quad Q_{c s} \geq 0 ; \quad X_{j} \geq 0 ; \quad Y_{i, j} \geq 0 .
\end{aligned}
$$

$P_{\mathrm{cs}}$ is the price of corn stover in dollar per ton. $Q_{\mathrm{cs}}$ is denoted as the quantity of corn stover sold in ton. $Y_{i, j}$ is denoted as corn stover harvested in ton in period $i$ of corn grain harvested in period $j$ with $i>j . G_{i, j}$ is defined as corn stover harvest cost in dollar per ton. $b_{i}$ is denoted as labor time required per acre to harvest corn grain in period $i . h_{i, j}$ is denoted as labor time required per ton to harvest corn stover in periodi of corn grain harvested in period $j . k_{i, j}$ is defined as baling time required per ton to bale corn stover in period $i$ of corn grain harvested in period $j . \widetilde{\mathrm{BFT}}_{i}$ represents stochastic baling field time expressed in hours available in each period i. $L$ is defined as total farm land acres available for corn grain harvest. $m_{j}$ represents stover yield in ton per acre of grain harvested in period $j$.

The objective function (see (14)) of the optimization problem is to quantify the net return potential associated with harvesting corn grain and stover separately using conventional technology. We assume that a conventional tractor and baler are used to harvest stover. Detailed explanations and specifications of the tractor and baler are described in the subsequent Section 2.7. Equation (16) balances corn stover sales with production. Since corn grain and stover are harvested separately, in the first period only corn grain can be harvested. All grain harvests are assumed to be completed by the end of the third period (i.e., $j=1, \ldots, 3$ ). Stover baling starts in the second period and ends in the final period (i.e., $i=2, \ldots, 4$ ). Equation (18) limits the total amount of labor time available for harvesting corn grain in the first period. Equation (19) constrains the total amount of labor time available for harvesting both corn grain and stover. Equation (20) restricts the total amount of labor time available for harvesting and baling corn stover in the final period. Equation (21) prohibits stover baling time from exceeding the limits. Equation (22) limits the total land acres available for corn grain harvesting. Equation (23) restricts the total corn stover harvested in future period $i$ to not exceed the total current supply availability in period $j$.

2.4. Corn Cob and Stover Yield Estimation. Crop residue cover is very important for preventing water and wind erosion during winter months following harvest. Wind erosion is a serious problem in North Dakota, especially in the eastern part of the state $[15,16]$. The amount of stover/cob that can be removed for biofuel production can be estimated using the following equation:

$$
\begin{aligned}
\text { Rstover }(\text { Rcob })= & \text { Grain Yield } \times \text { Weight } \times \text { SGR }(\text { CGR }) \\
& \times \text { Removal } \% \times[1-\text { Moisture } \%]
\end{aligned}
$$

Rstover/Rcob is the quantity of removable stover/cob in dry ton per acre. Grain yield is the weighted average yield of grain crop in bushels per acre. Weight is the weight of grain in 
short ton per bushel converted by dividing bushel weight of 56 pounds per bushel with 2,000 pounds per short ton. SGR is defined as a stover-to-grain ratio and it is assumed to be $1: 1$ based on Lal [17]. CGR is defined as a cob-to-grain ratio and it is calculated as 1:5.6 based on Wiselogel et al. [18]. Removal\% is the percent of stover/cob that can be removed for biofuel production. Considering wind erosion and other factors, we assume that 35 percent of corn stover can be removed from farm fields [19]. Since CVEC [9] and Roberts [20] suggest that removal of corn cobs may have little impact on soil productivity, Removal\% for cob is assumed to be one. Moisture\% is the percent of moisture content contained in stover/cob and is assumed to be 20 percent for both cobs and stover. Grain yield data were obtained from the USDA National Agricultural Statistics Service. The yield data are based on the five-year (2005 to 2009) average data by county in North Dakota. Estimated results for corn stover and cob availability in dry ton in North Dakota are reported in Table 1 by climatic region.

2.5. Cost Estimation for Corn Grain Harvesting. Corn grains are assumed to be harvested using a $275 \mathrm{HP}$ combine. Combine horse power, corn head width, life, annual hours of use, speed, field efficiency, fuel price, list price (which includes corn and grain head prices), and labor costs listed in Table 2 were obtained from Lazarus and Smale [21]. Fuel consumption, capacity of combine, and fixed and repair costs are computed based on the method and formulas illustrated in Edwards [22]. Fuel cost is obtained by multiplying fuel consumption with fuel price. Lubrication cost is assumed to be $15 \%$ of fuel cost. Variable cost is calculated by adding up repair, fuel, lubrication, and labor costs. Total harvest cost for corn grain using a $275 \mathrm{HP}$ combine is computed to be $\$ 28.71$ per acre as shown in Table 2.

2.6. Cost Estimation for Simultaneous Corn Grain and Cob (One-Pass) Harvesting. Corn cob harvest cost is estimated using whole cob harvest option. According to Shirek [23] and Wehrspann [24], one-pass cob harvester like Cob Caddy involves little modification to the combine and uses equipment available commercially to harvest whole cobs. Due to its simplicity, efficiency, and commercial availability, the one-pass cob harvest method is employed to estimate corn cob harvest cost. We assume that the one-pass cob harvest method requires farmers to use a self-propelled $275 \mathrm{HP}$ corn combine harvester and a pull-behind wagon-style cob harvester. Table 3 describes the machinery operation and estimated cost information for cob collection operation. The method of cost estimation for corn combine in Table 3 is exactly the same as that in Table 2. The main difference between the two tables in corn combine usage is the speed traveled and the capacity of combine.

Harvesting corn cobs requires an attachment of cob harvester to the back of corn combine. According to CVEC [9], this can slow down the corn grain harvest time by as much as half. Because of the use of cob harvester, the speed

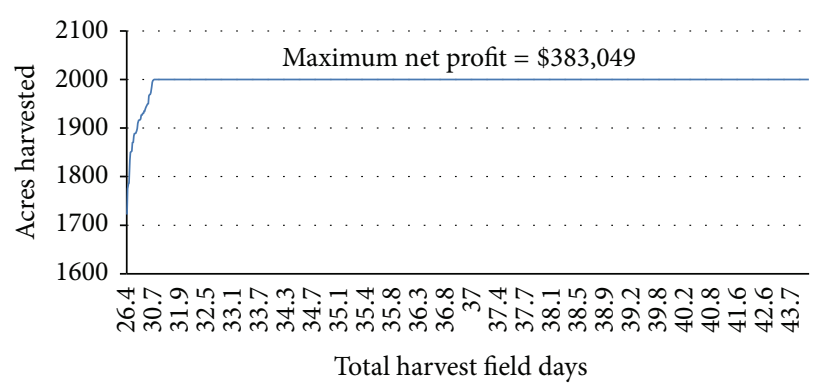

FIGURE 1: Relationship between corn grain acres harvested and availability of harvest field days.

of corn combine is assumed to reduce by $50 \%$ (i.e. from $4 \mathrm{mph}$ to $2 \mathrm{mph}$ in Table 3 ) for the baseline case. Another field study conducted by Darr [25] using stover harvester shows similar results. This would result in the corn combine capacity being reduced by half compared to the combine capacity in corn grain only harvest option. As a consequence of this reduction in corn combine speed and capacity, total harvest cost for corn grain increases from $\$ 28.71$ per acre to $\$ 57.43$ per acre. Similar cost computations are implemented for cob harvester as shown in Table 3. The data for cob harvester were obtained by personal communication with Vermeer Corporation. Since cob harvester is attached to the back of corn combine, no additional labor is required to operate the machine and its capacity is dependent on the capacity of corn combine. The cost of harvesting corn cob is calculated to be $\$ 19.36$ per acre. Table 4 reports the scenarios for the impact of changes in corn combine speed/capacity due to the use of cob harvester on corn grain and cob harvest costs. The table clearly shows that the impact of corn combine speed/capacity on grain and cob harvest costs can be significant.

2.7. Cost Estimation for Separate Corn Grain and Stover (Two-Pass) Harvesting. Under this option, we assume that a tractor and baler are used to harvest corn stover and that a self-propelled $275 \mathrm{HP}$ corn combine is used to harvest corn grain. Because corn grain and stover are harvested separately, there will be no slowdown in combine harvest speed/capacity. Thus, corn grain harvest cost will be identical to that of Table 2. It is assumed that a $130 \mathrm{HP}$ MFWD Tractor is used along with $3 \times 3$ Large Rectangular Baler to harvest stover. Specifications and data for the tractor and baler obtained from Lazarus and Smale [21] are shown in Table 5 which indicates that total harvest costs for the tractor and baler are summed up to be $\$ 10.76$ per acre. In addition, stover shredding and raking costs need to be included, since shredding of stover may be necessary because some of them will be in stalks anchored to the ground after grain harvesting. The anchored pieces of biomass are difficult to cut and bale in a single operation. Large pieces of biomass would make better bales but shredding followed by raking will accelerate field drying [3]. Based on Petrolia's [6] estimation, the total shredding and raking cost of $\$ 12.02$ per acre is added to total variable and fixed costs to generate the total stover harvest 
TABLE 1: Estimated corn stover and cob yield by North Dakota climatic division (2005-2009 average).

\begin{tabular}{|c|c|c|c|c|c|c|c|}
\hline \multirow{2}{*}{ Region } & \multirow{2}{*}{$\begin{array}{c}\text { Harvested acres } \\
\text { (Acre) }\end{array}$} & \multirow{2}{*}{$\begin{array}{c}\text { Land area } \\
\text { (Acre) }\end{array}$} & \multirow{2}{*}{$\begin{array}{c}\text { Density } \\
(\%)\end{array}$} & \multicolumn{2}{|c|}{ Stover availability } & \multicolumn{2}{|c|}{ Cob availability } \\
\hline & & & & (Ton/acre) & (Ton) & (Ton/acre) & (Ton) \\
\hline Northwest & 13,538 & $5,852,864$ & 0.23 & 0.44 & 5,917 & 0.22 & 3,019 \\
\hline North central & 72,434 & $4,379,872$ & 1.65 & 0.61 & 43,981 & 0.31 & 22,439 \\
\hline North east & 190,637 & $5,451,379$ & 3.50 & 0.75 & 143,355 & 0.38 & 73,140 \\
\hline West central & 36,781 & $5,523,571$ & 0.67 & 0.61 & 22,467 & 0.31 & 11,463 \\
\hline Central & 206,691 & $4,531,546$ & 4.56 & 0.79 & 163,703 & 0.40 & 83,522 \\
\hline East central & 493,067 & $3,545,363$ & 13.91 & 0.99 & 486,232 & 0.50 & 248,078 \\
\hline Southwest & 29,792 & $5,114,694$ & 0.58 & 0.33 & 9,964 & 0.17 & 5,083 \\
\hline South central & 92,891 & $5,006,605$ & 1.86 & 0.57 & 52,689 & 0.29 & 26,882 \\
\hline Southeast & 684,987 & $4,738,701$ & 14.46 & 1.03 & 704,635 & 0.52 & 359,508 \\
\hline State total & $1,820,818$ & $44,144,595$ & $4.60^{*}$ & $0.68^{*}$ & $1,632,943$ & $0.35^{*}$ & 833,134 \\
\hline
\end{tabular}

Note: harvested acres are weighted by yield. ${ }^{*}$ represents state average.

TABLE 2: Estimated corn grain harvest cost.

\begin{tabular}{lc}
\hline Variable & Corn combine \\
\hline Horse power $(\mathrm{hp})$ & 275.00 \\
Corn head width $(\mathrm{ft})$ & 20.00 \\
Life (year) & 12.00 \\
Annual hours of use & 300.00 \\
Fuel consumption (gal/hr) & 12.10 \\
Speed (mph) & 4.00 \\
Field efficiency $(\%)$ & 0.70 \\
Capacity $(\mathrm{acre} / \mathrm{hr})$ & 6.79 \\
Fuel price $(\$ / \mathrm{gal})$ & $\$ 2.60$ \\
List price $(\$)$ & $\$ 334,795.32$ \\
Fixed cost $(\$ / \mathrm{hr})$ & $\$ 104.02$ \\
Repair cost $(\$ / \mathrm{hr})$ & $\$ 37.20$ \\
Fuel cost $(\$ / \mathrm{hr})$ & $\$ 31.46$ \\
Lubrication cost $(\$ / \mathrm{hr})$ & $\$ 4.72$ \\
Labor cost $(\$ / \mathrm{hr})$ & $\$ 17.50$ \\
Variable cost $(\$ / \mathrm{hr})$ & $\$ 90.88$ \\
\hline Total cost $(\$ / \mathrm{hr})$ & $\$ 194.90$ \\
Total cost $(\$ / \mathrm{acre})$ & $\$ 28.71$ \\
\hline
\end{tabular}

cost of $\$ 22.78$ per acre (or $\$ 33.53$ per ton converted using stover yield of 0.68 ton per acre).

2.8. Data Description and Assumptions. Assumptions and data used to analyze the three models described above are reported in Table 6 . Corn price and production cost are, respectively, assumed to be $\$ 142.86$ per ton (or equivalently $\$ 4$ per bushel) and $\$ 356.92$ per acre. The production cost of corn varies depending on the size of farm. For the baseline case, the size of farm is assumed to be 2,000 acres. Corn production cost includes cost of using seed, fertilizer, chemicals, insurance, land, machinery, and building. Corn yield is assumed to be 4.04 ton per acre (or 144.27 bushel per acre). All these cost and yield data are based on five-year (2005-2009) average North Dakota data and obtained from FINBIN Farm Financial Database [26]. Corn harvest cost of
TABLE 3: Estimated corn grain and cob harvest cost using cob caddy harvest method.

\begin{tabular}{lcc}
\hline Variable & Corn combine & Cob harvester \\
\hline Horse power $(\mathrm{hp})$ & 275.00 & 115.00 \\
Corn head width $(\mathrm{ft})$ & 20.00 & \\
Life $($ year) & 12.00 & 10.00 \\
Annual hours of use & 300.00 & 300.00 \\
Fuel consumption (gal/hr) & 12.10 & 2.50 \\
Speed (mph) & 2.00 & 2.00 \\
Field efficiency $(\%)$ & 0.70 & 0.70 \\
Capacity $(\mathrm{acre} / \mathrm{hr})$ & 3.39 & 3.39 \\
Fuel price $(\$ / \mathrm{gal})$ & $\$ 2.60$ & $\$ 2.60$ \\
List price $(\$)$ & $\$ 334,795.32$ & $\$ 120,000.00$ \\
Fixed cost $(\$ / \mathrm{hr})$ & $\$ 104.02$ & $\$ 40.24$ \\
Repair cost $(\$ / \mathrm{hr})$ & $\$ 37.20$ & $\$ 18.00$ \\
Fuel cost $(\$ / \mathrm{hr})$ & $\$ 31.46$ & $\$ 6.50$ \\
Lubrication cost $(\$ / \mathrm{hr})$ & $\$ 4.72$ & $\$ 0.98$ \\
Labor cost $(\$ / \mathrm{hr})$ & $\$ 17.50$ & \\
Variable cost $(\$ / \mathrm{hr})$ & $\$ 90.88$ & $\$ 25.48$ \\
\hline Total cost $(\$ / \mathrm{hr})$ & $\$ 194.90$ & $\$ 65.72$ \\
Total cost $(\$ / \mathrm{acre})$ & $\$ 57.43$ & $\$ 19.36$ \\
\hline
\end{tabular}

TABLE 4: Impact of corn combine capacity on grain and cob harvest cost.

\begin{tabular}{lccc}
\hline Scenario & $\begin{array}{c}\text { Corn grain } \\
\text { harvest cost } \\
\text { \$ per acre }\end{array}$ & $\begin{array}{c}\text { Corn cob } \\
\text { harvest cost }\end{array}$ & Total \\
\hline $50 \%$ capacity reduction (base) & 57.43 & 19.36 & 76.79 \\
25\% capacity reduction & 38.28 & 12.91 & 51.19 \\
$0 \%$ capacity reduction & 28.71 & 9.68 & 38.39 \\
\hline
\end{tabular}

$\$ 28.71$ per acre is based on our estimated result in Table 2. Corn combine and labor have harvest capacity of $6.79 \mathrm{ac} / \mathrm{hr}$ and $5.43 \mathrm{ac} / \mathrm{hr}$, respectively. For the case of simultaneous corn grain and cob one-pass harvest option, corn combine capacity is assumed to reduce by half from $6.79 \mathrm{ac} / \mathrm{hr}$ to $3.39 \mathrm{ac} / \mathrm{hr}$. This $50 \%$ reduction in capacity is due to the use of cob harvester 
TABLE 5: Estimated corn stover harvest cost.

\begin{tabular}{lcc}
\hline & Tractor & Baler \\
\hline Horse power $(\mathrm{hp})$ & 130.00 & \\
Baler width $(\mathrm{ft})$ & & 20.00 \\
Bale weight (ton) & & \\
Life (year) & 12.00 & 12.00 \\
Annual hours of use & 450.00 & 250.00 \\
Fuel use (gal/hr) & 5.72 & \\
Speed (mph) & 5.00 & 5.00 \\
Field efficiency $(\%)$ & 0.80 & 0.80 \\
Capacity $(\mathrm{acre} / \mathrm{hr})$ & & 9.70 \\
Fuel price $(\$ / \mathrm{gal})$ & $\$ 2.60$ & \\
List price $(\$)$ & $\$ 118,889.00$ & $\$ 96,667.00$ \\
Fixed cost $(\$ / \mathrm{hr})$ & $\$ 21.96$ & $\$ 11.28$ \\
Repair cost $(\$ / \mathrm{hr})$ & $\$ 2.20$ & \\
Fuel cost $(\$ / \mathrm{hr})$ & $\$ 14.87$ & \\
Lubrication cost $(\$ / \mathrm{hr})$ & $\$ 2.23$ & $\$ 11.28$ \\
Labor cost $(\$ / \mathrm{hr})$ & $\$ 17.50$ & $\$ 45.61$ \\
Variable cost $(\$ / \mathrm{hr})$ & $\$ 36.80$ & $\$ 4.70$ \\
\hline Total cost $(\$ / \mathrm{hr})$ & $\$ 58.77$ & \\
Total cost $(\$ / \mathrm{acre})$ & $\$ 6.06$ & \\
\hline
\end{tabular}

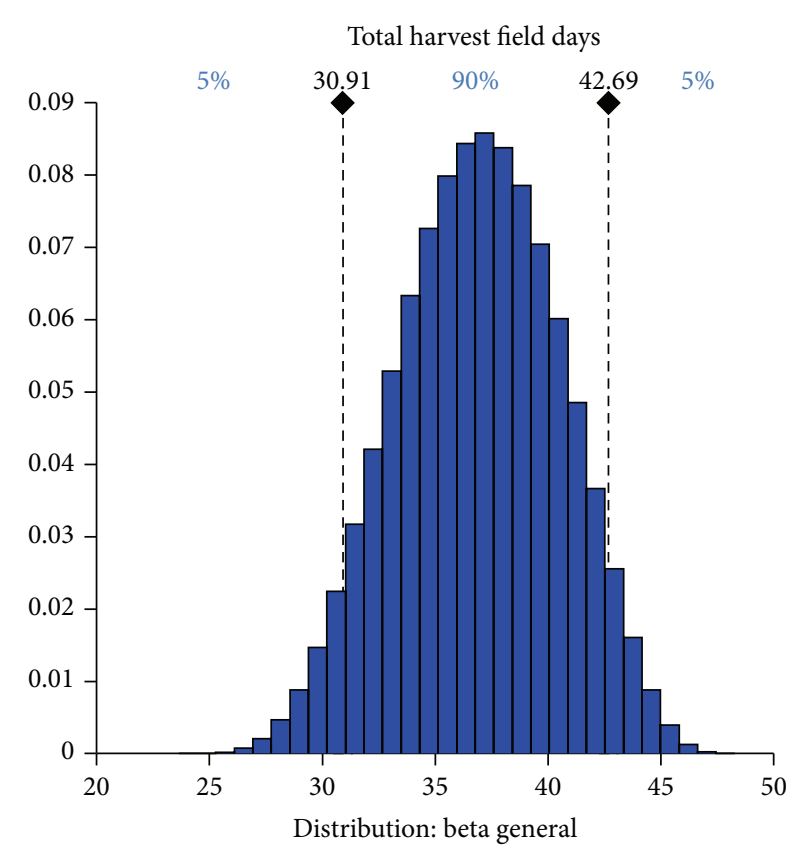

Figure 2: Histogram for harvest field days.

attached to the back of combine [9]. The combine capacity data is based on Lazarus and Smale [21] and labor capacity data is determined based on a factor of 0.80 [27]. For example, if the combine capacity is $6.79 \mathrm{ac} / \mathrm{hr}$ then the labor capacity is estimated to be $5.43(0.8 * 6.79) \mathrm{ac} / \mathrm{hr}$.

Corn cob and stover prices of $\$ 55 /$ ton and $\$ 45 /$ ton were assumed based on the information obtained from an ethanol company currently operating in the United States. Under the grain and cob one-pass harvest option, because of the use

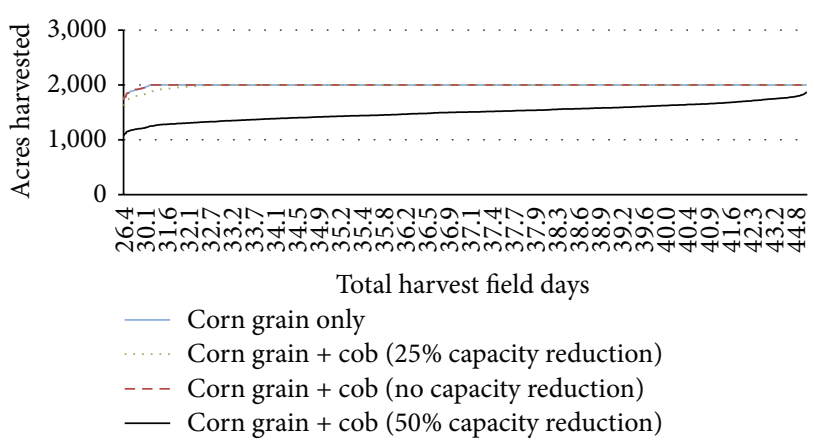

(a) Correlation between harvest field time and acres harvested

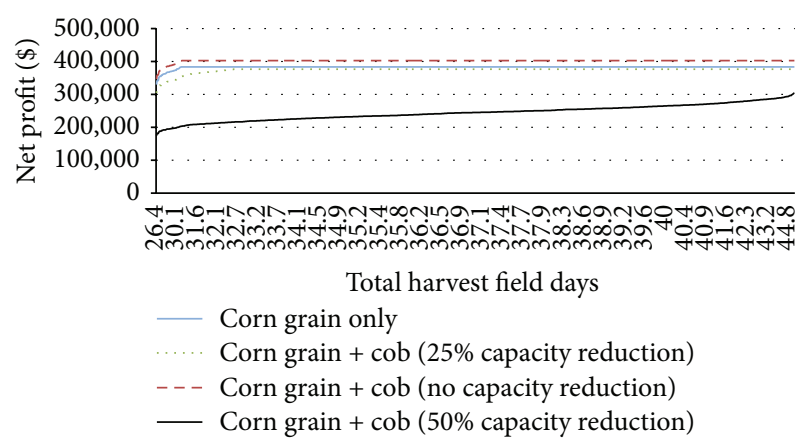

(b) Correlation between harvest field time and net farm profit

FIgURE 3: Comparison of stochastic scenario results.

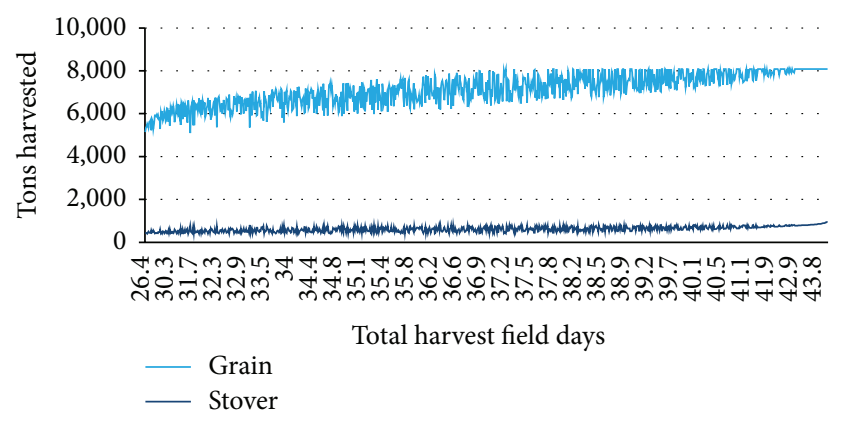

FIGURE 4: Relationship between corn grain and stover harvest.

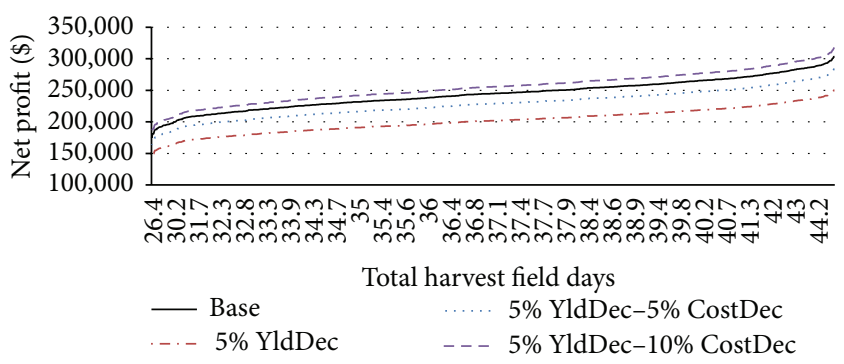

FIgURE 5: Scenarios for impact of yield and production cost on net farm profit for simultaneous corn grain and cob harvesting (assumed 50\% capacity slowdown due to cob harvesting). 
TABLE 6: Baseline assumptions used in the three harvest models.

\begin{tabular}{|c|c|c|c|}
\hline & Corn grain only & $\begin{array}{c}\text { Corn grain and cob } \\
\text { One-pass harvest }\end{array}$ & $\begin{array}{l}\text { Corn grain and stover } \\
\text { Two-pass harvest }\end{array}$ \\
\hline Corn price (\$/ton) & 142.86 & 142.86 & 142.86 \\
\hline Cob price (\$/ton) & - & 55.00 & - \\
\hline Stover price $(\$ /$ ton $)$ & - & - & 45.00 \\
\hline Corn production cost $(\$ / \mathrm{ac})$ & 356.92 & 356.92 & 356.92 \\
\hline Corn harvest cost $(\$ / a c)$ & 28.71 & 57.43 & 28.71 \\
\hline Cob harvest cost (\$/ac) & - & 19.36 & - \\
\hline Stover harvest cost $(\$ / \mathrm{ac})$ & - & - & 33.53 \\
\hline Corn yield (ton/ac) & 4.04 & 4.04 & 4.04 \\
\hline Cob yield (ton/ac) & - & 0.35 & - \\
\hline Stover yield (ton/ac) & - & - & 0.68 \\
\hline Combine capacity (ac/hr) & 6.79 & 3.39 & 6.79 \\
\hline Baler capacity $(\mathrm{ac} / \mathrm{hr})$ & - & - & 9.70 \\
\hline Labor capacity for grain harvest (ac/hr) & 5.43 & 5.43 & 5.43 \\
\hline Labor capacity for stover harvest (ac/hr) & - & - & 7.76 \\
\hline Total farm acres & $2,000.00$ & $2,000.00$ & $2,000.00$ \\
\hline
\end{tabular}

TABLE 7: Harvest field day data.

\begin{tabular}{lcccccccc}
\hline & From & To & 2005 & 2006 & 2007 & 2008 & 2009 & Mean average \\
\hline Period 1 & 24-Sep & 7-Oct & 9.90 & 11.60 & 11.70 & 11.10 & 9.30 & 10.72 \\
Period 2 & 8-Oct & 21-Oct & 10.70 & 10.30 & 9.60 & 8.20 & 4.30 & 8.62 \\
Period 3 & 22-Oct & 5-Nov & 11.90 & 10.90 & 13.10 & 10.20 & 5.40 & 10.30 \\
Period 4 & 6-Nov & 19-Nov & 9.00 & - & 12.70 & 6.40 & 12.90 & 10.25 \\
\hline
\end{tabular}

of cob harvester which slows down grain harvest capacity, corn grain harvest cost increases from $\$ 28.71$ to $\$ 57.43$ per acre. Corn cob harvest cost of $\$ 19.36$ per acre and cob yield of 0.35 ton per acre are based on our estimated results shown in Tables 1 and 3. Under the grain and stover twopass harvest option, corn stover can be harvested only after grain is harvested. Thus, grain harvest capacity will not be affected under this option. As illustrated above, our estimated stover harvest cost and state-average stover yield are $\$ 33.53$ per ton and 0.68 ton per acre respectively. Baler and labor baling capacities are respectively calculated to be $9.7 \mathrm{ac} / \mathrm{hr}$ and $7.76 \mathrm{ac} / \mathrm{hr}$. Labor baling capacity is determined based on a factor of 0.80 . Harvest field day data reported in Table 7 for North Dakota were collected from the USDA National Agricultural Statistics Service [28]. Each period of harvest field time is assumed to last for two weeks.

\section{Empirical Results}

Results can be deterministic or stochastic as farmer's net return will change if corn/cob/stover price, yield, and field time fluctuate. Deterministic results are the results that contain no risk or random component. On the other hand, stochastic results are estimated using a random component (in this case random harvest field time) to generate a sample of outcomes. For both deterministic and stochastic models, we assume that farmers spend 12 working hours per day harvesting corn grain and cobs, and baling stover. As discussed, there are a total of four harvest periods and each period is assumed to last for two weeks. For the baseline scenario, the maximum harvestable acreage or farm size is assumed to be 2,000 acres.

\subsection{Corn Grain Harvesting}

3.1.1. Deterministic Results. By incorporating data assumptions into the corn grain only harvest optimization model, deterministic optimal outcomes for net farm profit, corn grain sold, and harvested acres are generated and shown in Table 8 for two scenarios with differing harvest field time (expressed in hours) in each period. The table shows the positive correlation between corn acres harvested and harvest field time. In scenario one, about 106 corn acres are left unharvested due to harvest time limit and the shadow price of $\$ 1,040.89$ suggests that if corn combine harvest time can be increased by an additional hour, then farmers can benefit from their net profit increase from $\$ 362,783$ to $\$ 363,823$. In scenario two, with more harvest field hours available in each period, more corn grain acres can be harvested until farmers finish harvesting all corn acres in the final period. The shadow price of $\$ 191.52$ suggests that farmers are able to complete harvesting all 2,000 corn acres and if an additional corn acre is available for harvesting, farmers can increase their net profit by $\$ 191.52$. 
TABLE 8: Deterministic results for corn grain production.

\begin{tabular}{|c|c|c|c|c|}
\hline & Scenario 1 & Shadow price $(\$)$ & Scenario 2 & Shadow price $(\$)$ \\
\hline Net profit (\$) & $362,782.60$ & & $383,048.80$ & \\
\hline Corn grain sold (tons) & $7,652.51$ & & $8,080.00$ & \\
\hline \multicolumn{5}{|l|}{ Corn harvested acres } \\
\hline Period 1 & 697.07 & & 699.13 & \\
\hline Period 2 & 307.66 & & 562.17 & \\
\hline Period 3 & 461.79 & & 671.74 & \\
\hline Period 4 & 427.66 & & 66.96 & \\
\hline Total corn harvested acres & $1,894.18$ & 0.00 & $2,000.00$ & 191.52 \\
\hline \multicolumn{5}{|l|}{ Harvest field time (hours) } \\
\hline Period 1 & 128.26 & $1,040.89$ & 128.64 & 0.00 \\
\hline Period 2 & 56.61 & $1,040.89$ & 103.44 & 0.00 \\
\hline Period 3 & 84.97 & $1,040.89$ & 123.60 & 0.00 \\
\hline Period 4 & 78.69 & $1,040.89$ & 123.00 & 0.00 \\
\hline Total harvest field time & 348.53 & & 478.68 & \\
\hline
\end{tabular}

TABLE 9: Stochastic results for corn grain harvesting.

\begin{tabular}{|c|c|c|c|c|}
\hline Variable & Mean & Standard deviation & Minimum & Maximum \\
\hline Net profit (\$) & $382,338.10$ & $4,232.43$ & $329,838.33$ & $383,048.80$ \\
\hline Corn grain sold (tons) & $8,065.01$ & 89.28 & $6,957.58$ & $8,080.00$ \\
\hline \multicolumn{5}{|l|}{ Corn harvested acres } \\
\hline Period 1 & 684.79 & 45.21 & 358.88 & 451.42 \\
\hline Period 2 & 489.13 & 120.55 & 166.05 & 412.73 \\
\hline Period 3 & 591.74 & 134.63 & 208.39 & 505.21 \\
\hline Period 4 & 230.64 & 170.93 & 179.55 & 496.59 \\
\hline Total corn harvested acres & $1,996.29$ & 22.10 & $1,722.18$ & $2,000.00$ \\
\hline \multicolumn{5}{|l|}{ Harvest field time (hours) } \\
\hline Period 1 & 126.00 & 0.69 & 111.60 & 140.40 \\
\hline Period 2 & 90.00 & 1.85 & 51.60 & 128.40 \\
\hline Period 3 & 111.00 & 2.22 & 64.80 & 157.08 \\
\hline Period 4 & 115.80 & 1.88 & 76.80 & 154.68 \\
\hline Total harvest field time & 442.80 & 3.57 & 316.92 & 550.32 \\
\hline
\end{tabular}

3.1.2. Stochastic Results. Deterministic outcomes do not describe how farmers change their harvesting priorities or to what degree profitability is affected when faced with harvest time risk and limited field days. Using historical field day data and @Risk simulation software [29], 1,000 random numbers of field days (expressed in hours) are generated based on a uniform distribution. These random field days are incorporated into the corn grain only harvest model to estimate random outcomes which show the impact of harvest field time variations on net farm income, corn grain sold, and corn acres harvested. When simulating random outcomes we allow harvest field time to change and all other variables such as corn price, yield and cost are assumed to be constant. GAMS software [30] is used to simulate these random outcomes.

Simulated outcomes are reported in Table 9 and Figure 1. The table indicates that variations in harvest field time will have an impact on the net farm profit. Maximum net income that farmers can obtain from harvesting corn grain is $\$ 383,049$ with all 2000 farm acres harvested. Figure 1 implies that harvest field time and net profit are positively correlated until all farm acres are harvested that is, until profit maximization is achieved. As shown in the figure, farmers in North Dakota would need a total of 31 harvest field days with 12 working hours each day to finish harvesting 2,000 corn acres. Figure 2 depicts a distribution histogram for the total harvest field days available. It shows that with $90 \%$ confidence total harvest field days range from 30.91 to 42.69 days.

\subsection{Simultaneous Corn Grain and Cob Harvesting}

3.2.1. Deterministic Results. Deterministic results for simultaneous corn grain and cob harvesting are generated and reported in Tables 10(a) and 10(b). The results are generated based on three different corn combine capacity slowdown scenarios. If we assume that corn cob harvesting does not interfere with corn combine harvest capacity, then farmers can generate additional revenue of $\$ 19,140$ ( $\$ 402,188.80$ minus $\$ 383,048.80$ ) from selling 700 tons of corn cobs in 
TABLE 10: (a) Deterministic results for simultaneous corn grain and cob production. (b) Correspondent shadow price.

(a)

\begin{tabular}{lccc}
\hline & $50 \%$ capacity reduction & 25\% capacity reduction & No capacity reduction \\
\hline Net profit (\$) & $263,995.10$ & $376,588.80$ & $402,188.80$ \\
Corn grain sold (tons) & $6,555.48$ & $8,080.00$ & $8,080.00$ \\
Corn cob sold (tons) & 567.93 & 700.00 & 700.00 \\
Corn grain/cob harvested acres & & & 699.13 \\
$\quad$ Period 1 & 436.07 & 656.33 & 562.17 \\
$\quad$ Period 2 & 350.64 & 527.76 & 671.74 \\
Period 3 & 418.98 & 630.61 & 66.96 \\
$\quad$ Period 4 & 416.95 & 185.31 & $\mathbf{2 , 0 0 0 . 0 0}$ \\
Total corn grain/cob harvested acres & $\mathbf{1 , 6 2 2 . 6 4}$ & $\mathbf{2 , 0 0 0 . 0 0}$ & 128.64 \\
Harvest field time (hours) & & & 103.44 \\
$\quad$ Period 1 & 128.64 & 128.64 & 123.60 \\
Period 2 & 103.44 & 103.44 & 123.00 \\
$\quad$ Period 3 & 123.60 & 123.60 & 123.00 \\
$\quad$ Period 4 & 123.00 & & \\
\hline
\end{tabular}

(b)

\begin{tabular}{lccr}
\hline & & Shadow price $(\$)$ & \\
& 50\% capacity reduction & 25\% capacity reduction & No capacity reduction \\
\hline Total corn grain/cob harvested acres & 0.00 & 188.29 & 201.09 \\
Harvest field time (hours) & & & 0.00 \\
$\quad$ Period 1 & 551.51 & 0.00 & 0.00 \\
Period 2 & 551.51 & 0.00 & 0.00 \\
Period 3 & 551.51 & 0.00 & 0.00 \\
Period 4 & 551.51 & & 0 \\
\hline
\end{tabular}

TABLE 11: Deterministic results for corn grain and stover production.

\begin{tabular}{|c|c|c|c|c|}
\hline & Scenario 1 & Shadow price $(\$)$ & Scenario 2 & Shadow price $(\$)$ \\
\hline Net profit $(\$)$ & $377,650.31$ & & $394,060.00$ & \\
\hline Corn grain sold (tons) & $7,809.50$ & & $8,080.00$ & \\
\hline Corn stover sold (tons) & 647.37 & & 959.64 & \\
\hline \multicolumn{5}{|l|}{ Corn grain acres harvested } \\
\hline Period 1 & 699.13 & & 733.70 & \\
\hline Period 2 & 562.17 & & 690.00 & \\
\hline Period 3 & 671.74 & & 576.30 & \\
\hline Total corn grain acres harvested & $1,933.04$ & 0.00 & $2,000.00$ & 180.42 \\
\hline \multicolumn{5}{|l|}{ Corn Stover Harvested in Tons } \\
\hline Period 2 & 0.00 & -186.30 & 0.00 & 0.00 \\
\hline Period 3 & 0.00 & -186.30 & 201.21 & 0.00 \\
\hline Period 4 & 647.37 & 0.00 & 758.43 & 0.00 \\
\hline \multicolumn{5}{|l|}{ Harvest field time (hours) } \\
\hline Period 1 & 128.64 & $1,040.89$ & 135.00 & 60.37 \\
\hline Period 2 & 103.44 & $1,040.89$ & 126.96 & 60.37 \\
\hline Period 3 & 123.60 & $1,040.89$ & 144.27 & 60.37 \\
\hline Period 4 & 123.00 & 60.37 & 144.10 & 60.37 \\
\hline Total harvest field time & 478.68 & & 550.33 & \\
\hline
\end{tabular}


addition to selling 8,080 tons of corn grain. However, if cob harvesting results in the slowdown of corn combine harvest capacity, then farmers can incur a loss of $\$ 6,460$ for $25 \%$ capacity reduction scenario or a loss of $\$ 119,054$ for $50 \%$ capacity reduction scenario. The loss in revenue is mainly due to the slowdown in harvest capacity as a result of cob harvesting. Given that corn harvest time is constrained by the limited availability of harvest field time in each period, farmers would not be able to maximize their net returns because of the slowdown.

The $25 \%$ combine capacity reduction scenario in Table 10(a) shows that all 2,000 acres of grain and cob can be harvested but their net profit is reduced compared with the net profit of no capacity reduction scenario. This is because the $25 \%$ slowdown in combine harvest capacity results in an increase in corn grain and cob harvest costs (this is illustrated in Table 4) which decrease net profit. The table also shows that about 377 corn acres are left unharvested if corn combine harvest capacity slows down by $50 \%$. Either the availability of harvest field time would have to increase or farmers would have to invest in additional harvest equipment and labor to finish all the harvesting to achieve maximum profit potential. Shadow prices corresponding to the three scenarios are given in Table 10(b). They can be interpreted in a similar manner as was done for the corn grain only harvest case.

3.2.2. Stochastic Results. Assuming that other variables such as corn grain and cob prices, costs, and yields remain unchanged, variations in harvest field time will change the net farm income of producing corn grain and cob. Increase in the availability of harvest field time would increase the amount of corn grain and cob harvested and thus increase net farm profit as shown in Figures 3(a) and 3(b). For a 2000acre farm, all grain and cob can be harvested within 33 harvest field days for all the scenarios except $50 \%$ harvest capacity reduction scenario (Figure 3(a)). Harvest field time and net farm profits are positively correlated until all farm acres are harvested (Figure 3(b)). For the 50\% harvest capacity reduction scenario, more harvest field days will be needed to finish all the harvesting and achieve profit maximization. Field studies conducted by CVEC [9] and Darr [25] indicate that corn combine harvest capacity can be reduced by as much as $50 \%$ because of the use of cob/stover harvester. Results in the figure do not favor the simultaneous grain and cob harvesting because the reduction in combine harvest capacity causes net farm profit to be lower compared to the corn grain only harvest option. Hence, in that sense harvesting corn grain alone might be more profitable than harvesting a combination of grain and cob simultaneously as suggested in Figure 3(b).

\subsection{Separate Corn Grain and Stover Harvesting}

3.3.1. Deterministic Results. Results generated based on two different field time scenarios are reported in Table 11. In both scenarios we assume that farmers can spend 12 hours per day harvesting and baling stover using the available harvest field time. As described in Section 2, there are a total of four harvest periods and corn grain harvest must be completed within the first three periods. Stover harvesting and baling can take place only when corn grain harvest is completed. Hence, no stover can be harvested and baled in the first period and no corn grain can be harvested in the final period. All grain and stover harvest activities need to be completed within four harvest periods. In scenario one in the table, total acres of corn grain harvested (1,933 acres) fell short of maximum 2,000 acres. This is because part of the farmers' time has been allocated to harvesting and baling stover in the final period and some acres of corn would be left unharvested.

The first scenario in the table also shows that no stover is harvested in the second and third periods. This is due to the fact that farmers find it optimal to allocate all of their time to harvest corn grain instead of stover during these two periods. The negative shadow price of $\$ 186.3$ in the first scenario implies that if farmers were to attempt to harvest corn stover in either second or third harvest period, their net profit will decrease by $\$ 186.3$ per ton of stover harvested. As suggested in the table, all stover harvest time is optimally allocated to the final period since no grain can be harvested during this final period. The shadow prices of $\$ 1,040.89$ (for grain) and $\$ 60.37$ (for stover) in the first scenario indicate that it would be much more valuable for farmers to harvest corn grain than stover if an additional harvest field hour is available.

In the second scenario of Table 11, we assume that more harvest field time is available in each period as compared to the first scenario. As expected, farmers are able to finish harvesting all 2,000 corn acres in this second scenario as more time is available. The shadow price of $\$ 60.37$ in the second scenario suggests that if an extra harvest field hour is available, famers are better off harvesting stover since they are assumed to have perfect information and are expected to complete harvesting all corn grain acres on time. The maximum amount of stover harvested in the first scenario is about 647 tons and in the second scenario is 960 tons. The difference in the net profit between the first and second scenarios can be explained by the difference in corn stover sold or harvested.

3.3.2. Stochastic Results. Fluctuations in harvest field time will have an impact on the amount of corn grain and stover harvested which in turn will have an effect upon the net farm income as indicated in Table 12. Results in the table were simulated under the assumption that all other variables remain constant except harvest field time. The table suggests that as the availability of harvest field time increases farmers are willing to allocate a little more of their time to harvest stover in the second and third periods although the final period remains the critical period when farmers spend most of their time on harvesting and baling stover.

Figure 4 analyzes the relationship between corn grain and stover harvested in tons as the availability of harvest field time increases. The figure shows that, for a 2000-acre farm, the amount of corn grain and stover harvested can fluctuate depending on the harvest field time availability 
TABLE 12: Stochastic results for corn grain and stover harvesting.

\begin{tabular}{|c|c|c|c|c|}
\hline Variable & Mean & Standard deviation & Minimum & Maximum \\
\hline Net profit (\$) & $345,284.50$ & $34,234.02$ & $248,631.24$ & $394,055.77$ \\
\hline Corn grain sold (tons) & $7,133.24$ & 717.34 & $5,097.87$ & $8,080.00$ \\
\hline Corn stover sold (tons) & 620.64 & 123.44 & 404.47 & 959.63 \\
\hline \multicolumn{5}{|l|}{ Corn grain acres harvested } \\
\hline Period 1 & 684.79 & 45.21 & 606.58 & 762.99 \\
\hline Period 2 & 488.82 & 120.44 & 280.65 & 697.61 \\
\hline Period 3 & 592.04 & 134.98 & 352.23 & 853.91 \\
\hline Total grain acres harvested & $1,765.65$ & 177.56 & $1,261.85$ & $2,000.00$ \\
\hline \multicolumn{5}{|l|}{ Corn stover harvested in tons } \\
\hline Period 2 & 0.30 & 5.64 & 0.00 & 160.74 \\
\hline Period 3 & 10.87 & 34.74 & 0.00 & 224.53 \\
\hline Period 4 & 609.48 & 118.57 & 404.47 & 814.37 \\
\hline \multicolumn{5}{|l|}{ Harvest field time (hours) } \\
\hline Period 1 & 126.00 & 0.69 & 111.60 & 140.40 \\
\hline Period 2 & 90.00 & 1.85 & 51.60 & 128.40 \\
\hline Period 3 & 111.00 & 2.22 & 64.80 & 157.08 \\
\hline Period 4 & 115.80 & 1.88 & 76.80 & 154.68 \\
\hline Total harvest field time & 442.80 & 3.57 & 316.92 & 550.32 \\
\hline
\end{tabular}

TABLE 13: Stochastic results for corn grain and stover harvesting.

\begin{tabular}{|c|c|c|c|c|c|c|c|c|c|}
\hline \multirow{2}{*}{ Scenario } & \multicolumn{5}{|c|}{ Harvest field time (days) } & \multirow{2}{*}{ Stover (tons) } & \multirow{2}{*}{ Grain (tons) } & \multirow{2}{*}{ Acres harvested } & \multirow{2}{*}{ Net profit $(\$)$} \\
\hline & Period 1 & Period 2 & Period 3 & Period 4 & Total & & & & \\
\hline 1 & 9.32 & 4.56 & 5.63 & 6.90 & 26.41 & 435.90 & $5,139.14$ & $1,272.07$ & $248,631.24$ \\
\hline 2 & 9.49 & 6.14 & 8.09 & 6.44 & 30.15 & 406.42 & $6,247.95$ & $1,546.52$ & $300,858.30$ \\
\hline 3 & 9.87 & 6.62 & 6.31 & 12.30 & 35.10 & 776.95 & $6,005.55$ & $1,486.52$ & $293,616.77$ \\
\hline 4 & 9.35 & 10.22 & 10.34 & 10.09 & 40.00 & 637.26 & $7,881.73$ & $1,950.92$ & $380,958.94$ \\
\hline 5 & 11.29 & 10.55 & 11.66 & 11.57 & 45.08 & 910.00 & $8,080.00$ & $2,000.00$ & $393,486.50$ \\
\hline 6 & 10.56 & 10.40 & 11.84 & 12.55 & 45.34 & 926.74 & $8,080.00$ & $2,000.00$ & $393,678.47$ \\
\hline 7 & 10.74 & 10.46 & 12.94 & 11.35 & 45.48 & 935.53 & $8,080.00$ & $2,000.00$ & $393,779.29$ \\
\hline 8 & 10.65 & 9.81 & 12.68 & 12.71 & 45.84 & 958.53 & $8,080.00$ & $2,000.00$ & $394,043.10$ \\
\hline
\end{tabular}

in each period. The fluctuations of corn grain and stover harvested as available field time changes in each period can be explained numerically using Table 13 . For example, if we compare scenarios 1, 2 and 3 in the table, the differences in stover harvested in tons can be explained by the differences in harvest field time in the final period 4 when most stover harvesting and baling take place. In the table, harvest field time in the final period for scenario 3 is higher than that of scenario 1 or 2 , and consequently total stover harvested in the third scenario would be higher. Given the limited availability of harvest time, as more (less) labor time is allocated to harvesting stover less (more) would be available for harvesting corn grain and this would have an impact on net farm profit as illustrated in the first three scenarios in Table 13.

When total availability of harvest field time increases to above 40 days as shown in the table (scenario 5-8), farmers would be able to finish harvesting all 2000 corn grain acres within the first three periods and allocate their remaining time on harvesting stover. From the table (scenario 5-8), we can see that once farmers realize that they can finish harvesting corn grain on time, they are willing to increase their time and effort on harvesting and baling stover as the availability of harvest field time increases. This results in an increase in tons of stover harvested and consequently an increase in net profit. This explains why grain and stover lines in Figure 4 are getting smoother rather than fluctuating up and down once total harvest field days exceed above 40 . Generally, the figure shows that as harvest field time increases the quantities of corn grain and stover harvested tend to trend upward gradually.

\section{Impact of Farm Size and Tillage Practice on Cob and Stover Harvesting}

Changes in farm sizes can also have an impact on the amount of corn grain, cob, and stover harvested. Our results (not reported here to save space) suggest that, under the grain and cob one-pass harvest option as farm size increases, farmers would need to add more harvest capacity to finish harvesting both grain and cobs (as compared to the corn 
grain only harvest option) since the use of cob harvester slows down the harvest. Under the grain and stover twopass harvest option, as farm size increases the availability of harvest field time could become a very limited factor. Farmers would increasingly find it difficult to allocate their labor time on harvesting both grain and stover as farm size increases. Variations in the use of soil tillage system would result in changes in yield and production cost among farms with different soil types. This would have an impact on farmers' net returns of harvesting corn grain, cob and stover. Our evidence reported in Figure 5 for the grain and cob one-pass harvest option shows that a small decrease in corn yield due to changes in tillage practice results in a large decline in the net profit of harvesting corn grain and cob. The figure also indicates that the decline in yield must be accompanied by the reduction in production cost in order for net farm profit to improve.

\section{Summary and Conclusion}

By employing the three linear programming models with different corn grain and residue harvest options, net farm returns were analyzed under changing harvest field time in order to gain insights into the economic tradeoffs between corn grain and cob/stover harvest activities in North Dakota. Emphasis was placed on understanding the impact of harvest field time on profit maximizing potential of corn farmers. Harvest field time can be very limited in North Dakota because of rainfall and early frost. Randomized fall harvest field times were incorporated into our models to create stochastic outcomes which show that variations in the availability of field time can have a great impact on net farm profits.

Among the three harvest options analyzed, simultaneous corn grain and cob one-pass harvest method may not be an optimal choice for biomass feedstock production unless farmers are compensated for their potential losses due to harvest capacity slowdown. On the other hand, time allocation is the major problem when farmers choose the option of harvesting corn grain and stover separately under the two-pass harvest method. If more labor time is allocated to harvesting stover, less would be available for harvesting corn grain and this would impact farmers' net profits. Because part of farmers' time has to be allocated to harvesting and baling stover, with limited availability of harvest field time some acres of corn grain could be left unharvested. In addition to limited harvest field time, another problem associated with harvesting and baling corn stover is the moisture content. High stover moisture content can affect harvest timing and result in storage losses $[31,32]$. Due to low temperatures and frequent rainfall during fall harvest season, the time required for stover to reach baling moisture after corn grain harvest has been reported to take from several days to weeks $[32,33]$. This will further limit the availability of harvest field time. Examining the impact of stover moisture content on harvest field time limits is beyond the scope of this paper. This will be an interesting topic to consider for future studies.
Because of limited harvest field time in North Dakota, a frequent suggestion is for farmers to hire additional labor to operate the farm machinery. However, additional farm labor is difficult to find in rural areas of the state. At present, labor shortage is becoming more acute in the state due to the rapidly rising oil and gas production and coupled with the fact that the state has the lowest unemployment rate in the nation. Moreover, large tractors and new stover collection equipment are highly sophisticated. Any new farm laborer would need extensive training and oversight, again burdening farmers who are already busy during harvest time. Furthermore, farmers are unwilling to take any risk of holding a large inventory of corn cob/stover and prefer to have an external party bale, store, and transport the goods [34]. Based on our evidence in this paper, we believe that it would be more efficient economically to allow an external party (either a biofuel firm or a firm that specializes in collecting biomass feedstock) to participate and invest in cob/stover harvest business.

\section{Acknowledgments}

The authors would like to thank anonymous referees for their valuable and insightful comments. This study is dedicated to the memory of Cole Gustafson, a devoted biofuel economist and an inspiring colleague, who passed away on April 28, 2012. Funding for this research was provided by the US Department of Energy through Sun Grant Initiative under the title "Prioritizing Corn Harvest and Biomass Collection Activities in North Dakota-A Weather Risk Analysis."

\section{References}

[1] B. A. McCarl, T. A. Maung, and K. T. Szulczyk, "Could bioenergy be used to harvest the greenhouse: an economic investigation of bioenergy and climate change?" in Handbook of Bioenergy Economics and Policy, M. Khanna, J. Scheffran, and D. Zilberman, Eds., pp. 195-218, Springer, New York, NY, USA, 2009.

[2] D. O’Brien, "Corn Market Supply Questions for Late WinterSpring 2010," 2010, http://www.agmanager.info/marketing/outlook/newletters/archives/GRAIN-OUTLOOK_01-27-10.

[3] S. Sokhansanj and A. F. Turhollow, "Baseline cost for corn stover collection," Applied Engineering in Agriculture, vol. 18, no. 5, pp. 525-530, 2002.

[4] P. W. Gallagher, M. Dikeman, J. Fritz, E. Wailes, W. Gauthier, and H. Shapouri, "Supply and social cost estimates for biomass from crop residues in the United States," Environmental and Resource Economics, vol. 24, no. 4, pp. 335-358, 2003.

[5] R. D. Perlack and A. F. Turhollow, "Feedstock cost analysis of corn stover residues for further processing," Energy, vol. 28, no. 14, pp. 1395-1403, 2003.

[6] D. R. Petrolia, "The economics of harvesting and transporting corn stover for conversion to fuel ethanol: a case study for Minnesota," Biomass and Bioenergy, vol. 32, no. 7, pp. 603-612, 2008.

[7] A. F. Turhollow and S. Sokhansanj, "Costs of harvesting, storing in a large pile, and transporting corn stover in a wet form," Applied Engineering in Agriculture, vol. 23, no. 4, pp. 439-448, 2007. 
[8] C. R. Gustafson, T. A. Maung, D. Saxowsky, J. Nowatzki, and T. Miljkovic, "Economics of Sourcing Cellulosic Feedstock for Energy Production,” 2011, http://ageconsearch.umn.edu/ bitstream/103260/2/AAEAPaper1_042711.pdf.

[9] Chippewa Valley Ethanol Company (CVEC), "Corn Cobs as Sustainable Biomass for Renewable Energy, a Fieldto-Facility Demonstration and Feasibility Study," 2009, http://www.auri.org/wp-content/assets/legacy/research/CVEC _Final_Report_to_Office_of_Energy_Security_30.pdf.

[10] D. Zych, "The Viability of Corn Cobs as a Bioenergy Feedstock," 2008, http://renewables.morris.umn.edu/biomass/documents/ Zych-TheViabilityOfCornCobsAsABioenergy Feedstock.pdf.

[11] A. Bouzaher and S. Offutt, "Stochastic linear programming model for corn residue production," Journal of the Operational Research Society, vol. 43, no. 9, pp. 843-857, 1992.

[12] J. Apland, B. A. McCarl, and T. G. Baker, "Crop residue supply for energy generation: a prototype application to midwestern U.S.A. grain farms," Energy in Agriculture C, vol. 1, pp. 55-70, 1981.

[13] M. J. Erickson and W. E. Tyner, "The economics of harvesting corn cobs for energy," Purdue Extension ID417-W, Purdue University, West Lafayette, Ind, USA, 2010, http://www.agecon.purdue.edu/papers/biofuels/ID_417_W.pdf.

[14] J. Apland, "Incorporating field time risk into a stochastic programming model of farm production," Staff Paper P90-11, Department of Agricultural and Applied Economics, University of Minnesota, Minneapolis, Minn, USA, 1990.

[15] L. J. Cihacek, M. D. Sweeney, and E. J. Deibert, "Characterization of wind erosion sediments in the Red River Valley of North Dakota," Journal of Environmental Quality, vol. 22, no. 2, pp. 305-310, 1993.

[16] S. J. Van Donk, S. D. Merrill, D. L. Tanaka, and J. M. Krupinsky, "Crop residue in North Dakota: measured and simulated by the wind erosion prediction system," Transactions of the ASABE, vol. 51, no. 5, pp. 1623-1632, 2008.

[17] R. Lal, "World crop residues production and implications of its use as a biofuel," Environment International, vol. 31, no. 4, pp. 575-584, 2005.

[18] A. Wiselogel, S. Tyson, and D. Johnson, "Biomass feedstock resources and compositioneds," in Handbook of Bioethanol: Production and Utilization, C. E. Wyman, Ed., pp. 105-116, Taylor and Francis Press, Washington, DC, USA, 1996.

[19] D. O. Hall, F. Rosillo-Calle, R. H. Williams, and J. Woods, "Biomass for energy: supply prospects," in Renewable Energy: Sources For Fuels and Electricity, T. B. Johansson, H. Kelly, A. K. Reddy, and R. H. Williams, Eds., pp. 593-651, Island Press, Washington, DC, USA, 1993.

[20] M. C. Roberts, "Biomass Availability in Northwest Ohio," 2009, http://ohioline.osu.edu/aex-fact/pdf/0541.pdf.

[21] W. F. Lazarus and A. Smale, "Farm Machinery Cost Estimation Spreadsheet (MACHDATA.XLS)," 2010, http://www.apec .umn.edu/faculty/wlazarus/tools.html.

[22] W. Edwards, "Estimating Farm Machinery Costs," 2009, http://www.extension.iastate.edu/agdm/crops/pdf/a3-29.pdf.

[23] M. Shirek, "Going Beyond the Corn Kernel," 2008, http://www .ethanolproducer.com/article.jsp?article_id=3626\&q=\&page $=1$.

[24] J. Wehrspann, "Concept Cob Collectors," 2009, http://farmindustrynews.com/farm-equipment/0201-concept-cob-collectors.
[25] M. Darr, "Evaluation of In-field Corn Stover Densification and Interaction with Storage Quality, Logistics, and Production Costs," 2010, http://ncsungrant1.sdstate.org/upload/ Microsoft-PowerPoint-Darr_SunGrant.pdf.

[26] FINBIN Farm Financial Database, "Crop Summary Reports," 2013, http://www.finbin.umn.edu/CropEnterpriseAnalysis/Default.aspx.

[27] University of Tennessee Extension, "Farm Machinery Custom Operation and Machinery Ownership Considerations," 2013, http://www.utextension.utk.edu/managecamp/custom\%20 work.pdf.

[28] USDA National Agricultural Statistics Service, "Crop Progress and Condition Report," 2005-2009, http://www.nass .usda.gov/Statistics_by_State/North_Dakota/Publications/Crop_ Progress_\&_Condition/index.asp.

[29] Palisade Corporation, Risk 4.5-Professional Edition. Software, Palisade Corporation, New York, NY, USA, 2009.

[30] “GAMS Development Corporation," http://www.gams.com/.

[31] K. J. Shinners and B. N. Binversie, "Harvest and storage of wet corn stover as a biomass feedstock," ASAE Paper 041159, ASAE, St. Joseph, Mich, USA, 2004.

[32] K. J. Shinners and B. N. Binversie, "Fractional yield and moisture of corn stover biomass produced in the Northern US Corn Belt," Biomass and Bioenergy, vol. 31, no. 8, pp. 576-584, 2007.

[33] D. A. Glassner, J. R. Hettenhaus, and T. M. Schechinger, "Corn stover collection project," in Proceeding of the BioEnergy '98: Expanding BioEnergy Partnerships, pp. 1100-1110, 1998.

[34] T. A. Maung, C. R. Gustafson, D. Saxowsky, T. Miljkovic, and J. Nowatzki, "Market information on sourcing cellulosic feedstock for biofuel production in Northern plains region of the United States," Journal of Agricultural Science and Technology A, vol. 2, pp. 10-23, 2012. 

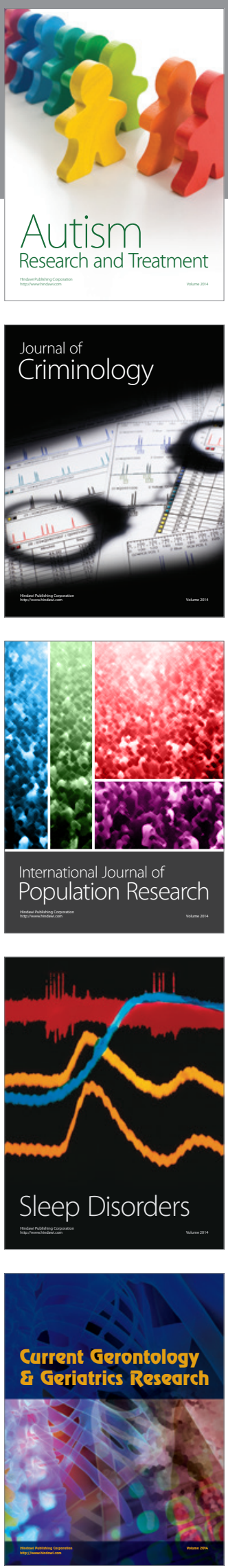
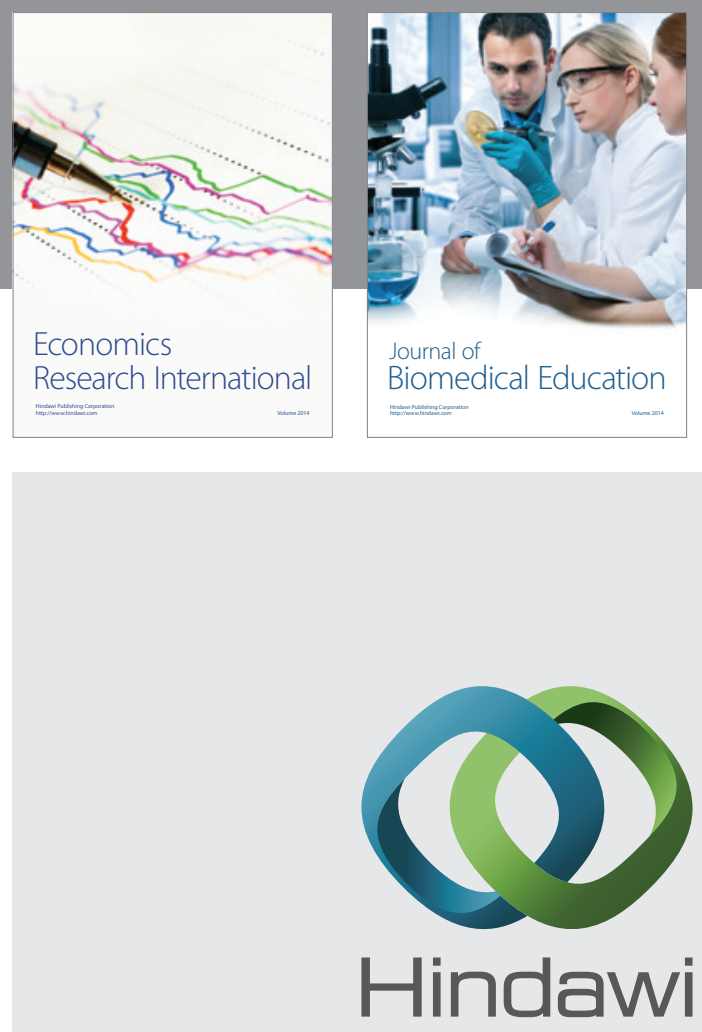

Submit your manuscripts at

http://www.hindawi.com
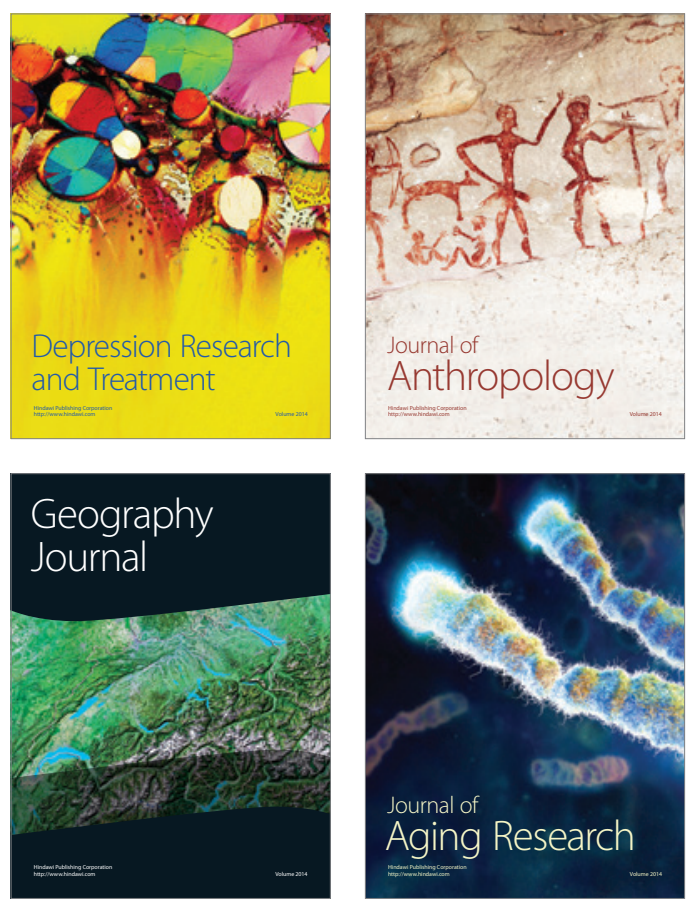
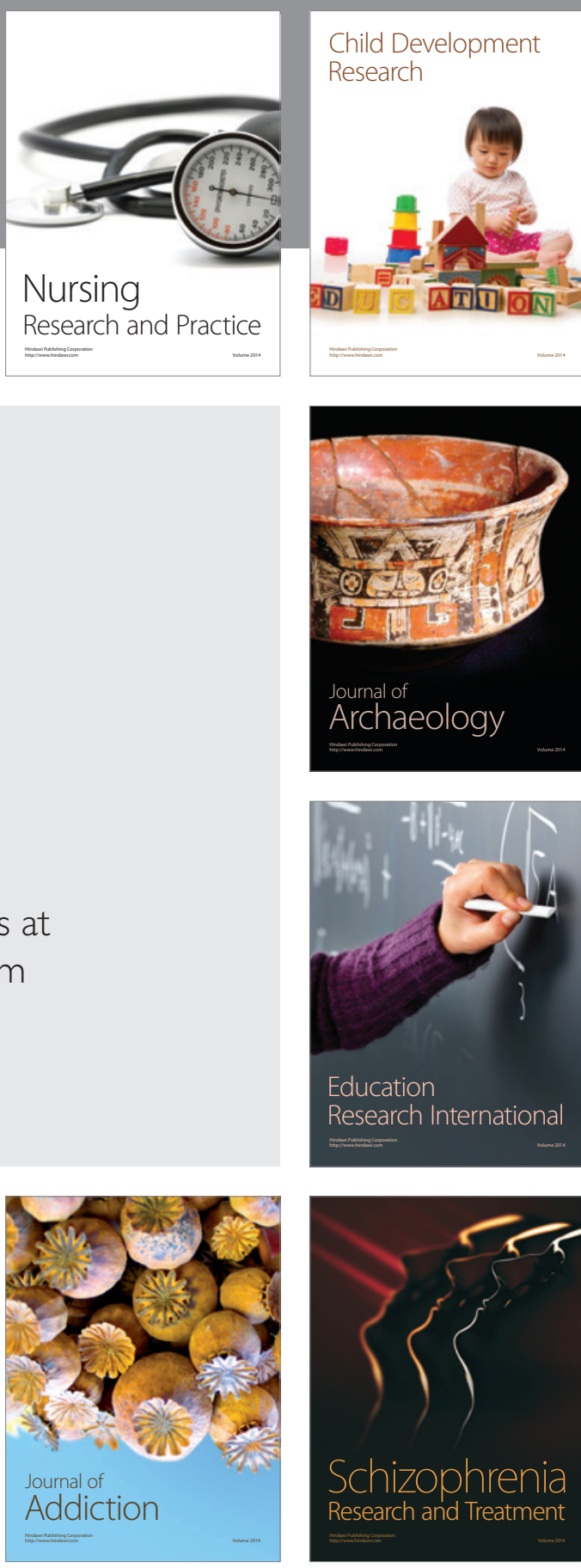

(D)
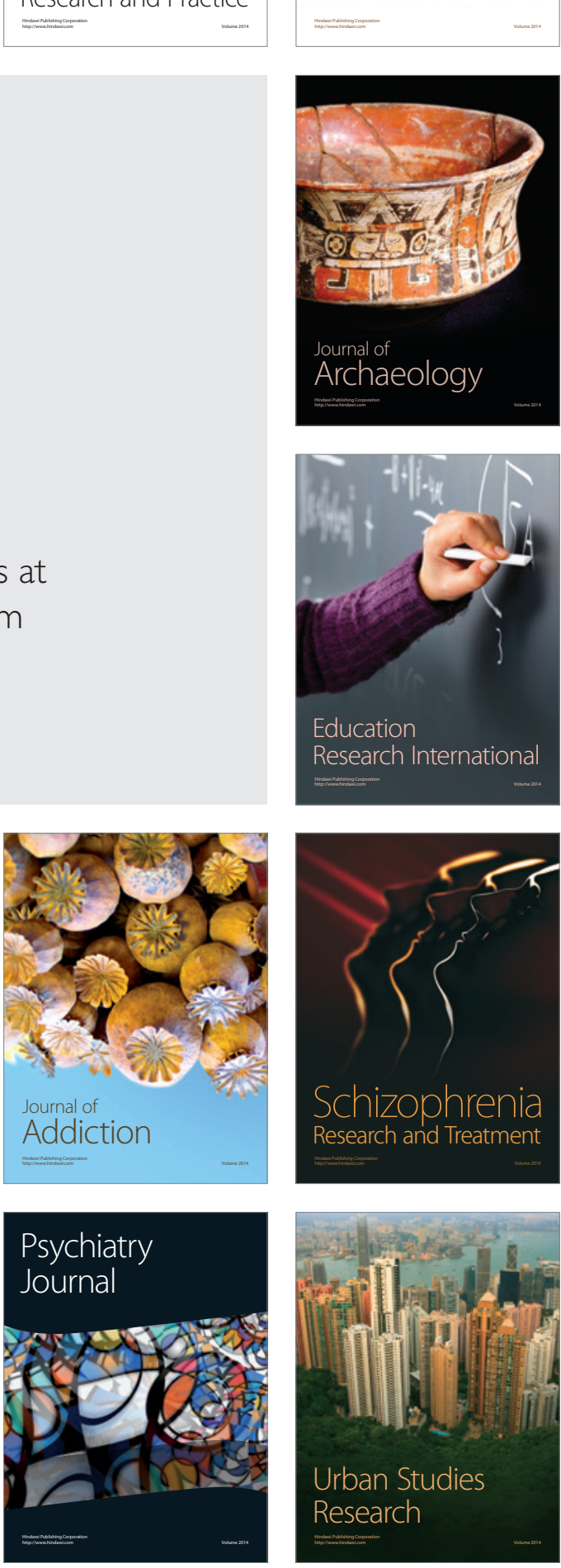